\title{
DEVELOPMENT OF CULTURAL TOURISM PRODUCT IN TAMAN MINI INDONESIA INDAH
}

\author{
Annisa Rahma Pramitha, Made Adhi Gunadi, Meizar Rusli \\ Tourism Faculty, University of Pancasila
}

\begin{abstract}
Indonesian cultural resources according to the World Economic Forum is ranked 38 of 140 countries. One of the tourist destinations in Indonesia that use cultural resources as tourist attraction is Taman Mini Indonesia Indah (TMII). Along with the modernization of tourist interest, TMII establish cooperation to develop new tourist attractions. However, activities of majority tourists during their visit to TMII is just walking around, take pictures, recreation, or sport. Tourists cultural tourism experience are lack, whereas TMII have vision to be the leading of cultural tourism destination. This research aimed to identify the concept of cultural tourism products that can be applied in TMII based on tourists motivation, tourism attraction in TMII, and activities in demand by tourists. This research used descriptive method with qualitative approach. Results of data analysis show that the physical or physiological motivation is the highest motivation chosen by the respondents, tourism attraction that gets the highest score is the architecture, and the activity of interest is sightseeing activities. These three variables are matched with the criteria of socio-cultural tour and two things that forming total experience. Hence, this research proposed a formula of tourism product that can be applied and promoted in TMII as a cultural tourism program, so that tourists can get physical activity in the spot that has architecture attraction, and provide more cultural tourism experience but still superficial.
\end{abstract}

Keywords: Tourism planning, Tourism Product, Cultural Tourism, total experience, product formula

\section{Introduction}

The World Tourism Organization (UNWTO) reported in the Annual Report 2013, that since the year 2012 to 2013 the growth rate of people traveling up to $5 \%$, or increased by about 52 million international tourists. Southeast Asia is a major sub-region with the largest international tourism demand, about more than 10\%. Based on data in The Travel \& Tourism Competitiveness Report 2013, which was reported by the World Economic Forum (WEF), the competitiveness of Indonesian tourism in 2013 is ranked 70 with the acquisition value of 4.0 from the value range $1-7$. Overall, natural resources, cultural resources, and human resources in the field of tourism in Indonesia is ranked 31 of 140 countries that exist in the WEF data. Indonesian cultural resources ranked 38 with a value of 3.5. 
One of the tourism destinations in Indonesia that use cultural resources as tourist attraction is Taman Mini Indonesia Indah (TMII). TMII which is located in East Jakarta has been designated as the Institution of Indonesian Cultural Preservation by the Minister of Culture and Tourism letter No. KM.21/PW.007/MKP/2011. Along with the development of tourism in Indonesia, TMII establish cooperation with private parties to develop tourist attractions. When Snowbay was built in 2008, the number of TMII visitors increased to 3,934,097 people. In 2009, Snowbay opened and visitors be increased to $4,103,279$. The largest percentage increase in the number of visitors occurred in 2010 , one year after Snowbay officially opened, amounting to $14.52 \%$. The number of visitors continues to increase until the year 2012, as many as 5,039,633 people. These data indicate that the Snowbay as new attractions at TMII able to attract more visitors. But the opposite happened in 2013. The total number of visitors TMII reduced by more than 430,000 people, or with a percentage decrease of $8.60 \%$. Despite the increase happened again in 2014, but did not reach 100,000 visitors. This data can be used as a rationale that Snowbay can not be the mainstay to increase the number of TMII visitors continuously. Based on previous observations conducted by researchers in September 2014 to November 2014, activities of majority tourists who visit TMII is just walking around, take pictures, recreation, or sport (jogging/biking). Cultural tourism experience are less obtained by tourists. In fact, the main attraction of TMII is Indonesian culture.

With a background that has been described, it should be done research on cultural tourism product planning in TMII. It aims to improve TMII tourist attraction through various culture-based tourism activities for tourists. Expected tourist gets more cultural tourism experience, so tourism in TMII can be sustainable and Indonesian culture can be preserved. This study identified TMII tourist motivation, which cultural tourism activities is in demand, and what attraction that interesting for tourists. Such identification is used as a basis for planning of cultural tourism products that can be applied in TMII.

\section{Literature Review}

\section{Tourism Destination}

Jafari (2000) in Hermantoro (2015: 108) defines a tourism destination as a place where tourists aiming to spend their spare time away from home. Pitana \& Diarta (2009: 126) defines a tourism destination: "a place visited by a significant time during the course of a person compared to other places traversed during the trip."

According to Hermantoro (2015: 132), a tourism destination should have the main elements:

1) Tourist attraction: is the main pull factor that should have uniqueness and superiority. Tourist attraction besides something can be seen, it can also be done and felt. Tourist attraction differentiated on the basis of natural resources and cultural resources. Natural resources such as mountains, sea, and so on, while the cultural resources is everything related to the product of human culture, can be tangible or intangible product. 
2) Tourism facilities: the facilities involved in the fulfillment of basic needs of tourists during travel and their stay at tourism destinations. Singh (2009: 265) mentions tourism facilities such as accommodation, transportation, and other services (i.e. tourist information center).

3) Public facilities: necessary at certain times, such as hospitals, post offices, ATMs.

4) Accessibility: transport facilities that connect the origin area of tourists with tourism destinations, among tourism destinations, and in the tourism destinations. Accessibility is also often interpreted as ease of travel facilities, such as visa, access to information, and access to markets.

\section{Tourism Products}

Tourism product is any product that is marketed with the aim of attracting tourists (Hermantoro, 2015: 188). This product is then defined as the total experience that enrich the experience of tourists since his arrival at a tourism destination to return back to the region or country of origin. The total experience is obtainable from transportation, accommodation, food and beverages, attractions, entertainment, events, souvenirs, and others. Tourism product is a source of experience to be gained by tourists. To form the total experience, according to the COMCEC (2013) in Hermantoro (2015: 190), there are three things that must be considered:

1) Experiental: in the form of festivals, events, community, eating and drinking, entertainment, and so on.

2) Emotional: in the form of human, culture and history, hospitality.

3) Physical: in the form of infrastructure, natural resources, accommodation, restaurants and shops.

Characteristics of tourism products according to Sheldon (1997: 5-7) that is heterogeneous (heterogeneity), intangibles (intangibility), did not last long (perishability), international, and is a product of the service industry (service industry). Richardson and Flucker (2004: 49) in Pitana \& Diarta (2009: 128-129) suggests that a service has four characteristics:

1) Intangibility: can not be smelled, heard, seen, felt, and tasted. Services can only be shown in the concept. Travelers will have the experience, but after the service product purchased expires, the experience was also completed.

2) Inseparability: can not be separated from the provider. For example, if there is no tour operator or travel agent, then the tour and travel services product would not exist.

3) Variability: The service product providers can not provide the same services between providers with each other, at any time, and to every customer.

4) Perishability: can not be saved. For example, when an airline seat is not sold today, this airline revenue will be reduced. In contrast to the manufacturing products such as shoes. If the shoes are not sold today, it still can be saved for re-sale tomorrow and do not reduce the income of the seller.

\section{Tourism Product Planning}

Planning is a multidimensional activity that includes social, economic, political, psychology, anthropology, technology, and also efforts to make these factors be integrated. The planning process according to Gunn \& Var (2002) consists of five stages: 1) Setting goals and objectives, 2) Surveys, 3) Analysis 
and synthesis, 4) Policy formulation, and 5) Setting recommendations. Inskeep (1991) found the stages of the planning process also includes the preparation of a study before setting goals and objectives, and monitoring after the stage of recommendation (Hermantoro, 2015: 99).

Hermantoro describe the process of defining the tourism product as shown in Figure 1. According to him, the first stage in developing the tourism product is setting overall objectives. The second stage is to do market research and resources. Market research conducted to determine the specific market segments, while resources research conducted to determine the shape of resources development (to be limited or preferably free) and tourism destination selected zones to be developed. After the research is done, the next step is to match the target market segments with its resources, then determine tourism products that will be developed. The next stage after tourism product set is build support elements and do the marketing.

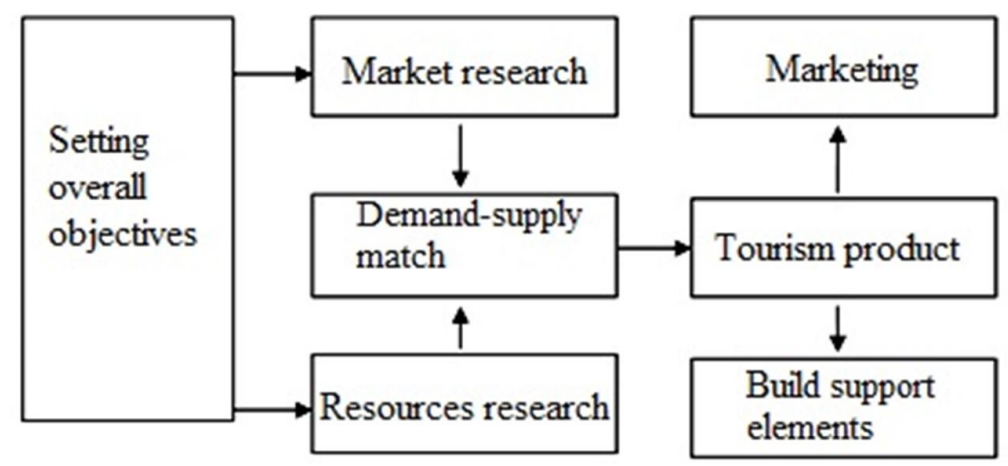

Source: Hermantoro (2015: 201)

Figure 1

Process of Defining The Tourism Product

\section{Travel Motivation}

According to Crompton (1979) in Guha (2009: 4-5), there are two classifications of travel motivations. This classification is the push factor and pull factors. The push factor is an intrinsic motivation (derived from the self-rating), and the pull factor is the extrinsic motivation (derived from things outside ourselves tourists). In Mohammad \& Som (2010: 41), Crompton identified seven push factors: 1) Out of the general environment, 2) Self-exploration, 3) Relaxation, 4) Prestige, 5) Regression (returning to the childhood region or country), 6) Increasing kinship, 7) Facilitating social interaction; and two pull factors: 1) Novelty and 2) Education.

Fendeli (2002: 178) in Savitri et al. (2013: 5) argues that the motivation classified into four types:

1) Physical or physiological motivation: relaxation, health, comfort, participate in sports activities, leisure, etc.

2) Cultural motivation: the desire to know the culture, customs, traditions, local arts, etc. 
3) Social or interpersonal motivation: visiting relatives, meet colleagues, pilgrimage, or escape from boredom.

4) Prestige motivation: motivation is based on psychological satisfaction. Travelers with this motivation aimed at lifting their social status.

\section{Cultural Tourism}

In the 1970s, some people travel to gain a deeper understanding of the culture in a destination (Tighe, 1986 in Mckercher and Du Cros, 2012: 1). This is realized by marketers and researchers of tourism, cultural tourism began to be recognized as a tourism product that is different from the others. Cultural tourism is only carried out by people who have better education, the tourists with the high economic level on seeking different things more than just sand, sun, and sea. This happens because the cultural tourism market in the 1990s was a tourist with a high-level profile (rich) with a mass activity.

Damardjati (1989 in Anonymous, 2015) write down the definitions of cultural tourism as a motion or tourist activities are stimulated by the sights of the tangible local culture: customs, rituals, rules of life, historical relics, works of art, crafts and so on. In other words, cultural tourism can be interpreted as a journey undertaken to spend leisure time, temporary, and the activities carried out while in tourism destinations is culture based. According to Nirwandar (2014: 101-103), in terminological, cultural and historical tourism is defined as a tourist attraction which is the result of a human thought, taste, and initiative.

Pitana \& Diarta (2009: 75-76) suggested seven cultural resources that can be used as a tourist attraction:

1) The historic buildings, sites, monuments, museums, art galleries, ancient cultural sites, etc.

2) Art and contemporary sculpture, architecture, textiles, handicrafts and arts centers, design centers, artist studios, the film industry and publishers, etc.

3) Performing arts, drama, dance, folk songs, street theater, photo exhibitions, festivals and other special events.

4) Religious relic such as temple, mosque, sites.

5) Activities and the way of life of local communities, the education system, studio, traditional technologies, work methods and systems of local life.

6) Travel (trekking) to historic sites using a unique transportation.

7) Try the local cuisine: see the preparation, how to create, serve, and eat.

Mckercher and Du Cros (2012: 144) also offers five types of cultural tourists based on how important the role of cultural tourism in the overall decision to visit the destination and how the experience is desirable. The fifth type of cultural tourists are as follows.

1) The purposeful cultural tourist: cultural tourism is a primary motivation for visiting a destination, and individual travelers receive in-depth cultural experience.

2) The cultural sightseeing tourist: cultural tourism is a primary or main reason for visiting a destination, but the experience gained is more superficial.

3) The serendipitous cultural tourist: tourists who travel not by reason of cultural tourism, but this tourists ultimately has a profound cultural tourism experience after participating. 
4) The casual cultural tourist: cultural tourism is a weak motivation to visit a destination and the experience is shallow.

5) The incidental cultural tourist: this type of travelers do not travel for reasons of cultural tourism but participate in some activities and have a shallow experience.

Gearing et al. (1976) in an article written by Patria (2014), suggests criteria for socio-cultural city tours as follows.

1) Customs: include clothing, food, the way of life of local residents, folk festival, handicrafts and other local products.

2) The art of the building: in the form of the types of local architecture, such as temples, mosques, churches, monuments, traditional building, and so on.

3) Stage, performances, and festivals: local specialties music, dance, sports weekends, competitions, games, and so on.

\section{Methodology}

This study was conducted in March 2015 until July 2015 in Taman Mini Indonesia Indah. The research strategy used is descriptive qualitative approach.

The data collection method used was survey (using a questionnaire), observation, interviews, and documentation. Determination of the respondents based on considerations TMII fairly wide area and tourist arrivals are likely to decline during the fasting month, so the researchers determined the three locations of data collection: 1) areas of West Sumatra Pavilion and Aeromovel Arsipel Station; 2) pathway area of West Kalimantan Pavilion, South Kalimantan Pavilion and East Kalimantan Pavilion; 3) Api Pancasila Monument area, north and south parking areas. Frankel and Wallen (1993) suggest that the minimum sample for descriptive research is as much as 100 respondents (Hendryadi, 2012). Data analysis performed in this study is based on data analysis techniques model of Miles and Huberman (Sugiyono, 2009: 246-253). Activities undertaken consisted of three stages: 1) Data reduction, 2) Data display, and 3) Conclusion drawing / verification.

\section{Results and Discussion}

\section{Profile of Respondents}

Conclusions from the survey of 100 respondents about their personal data is that the majority of respondents in productive age with high school education and status as students. Respondents were mostly local tourists because domiciled in Jakarta and has been visited TMII for 2 - 4 times until the time surveyed. Length of visiting time to is approximately 1 - 6 hours per visit with the majority of visiting partner are family and friend/s. 
Table 1

Respondents Profile

\begin{tabular}{|c|c|c|c|c|}
\hline \multicolumn{5}{|c|}{ Respondents Profile } \\
\hline \multirow{2}{*}{ Age } & $15-25$ year & $26-35$ year & $36-45$ year & $>45$ year \\
\hline & 57 & 26 & 12 & 5 \\
\hline \multirow{2}{*}{ Sex } & \multicolumn{2}{|c|}{ Woman } & \multicolumn{2}{|c|}{ Man } \\
\hline & \multicolumn{2}{|c|}{55} & \multicolumn{2}{|c|}{45} \\
\hline \multirow{2}{*}{ Last education } & $\begin{array}{c}\text { Junior High } \\
\text { School } \\
\end{array}$ & Senior High School & $\begin{array}{c}\text { Diploma/Bachelor } \\
\text { Degree }\end{array}$ & $\begin{array}{c}\text { Master/Doctoral } \\
\text { Degree }\end{array}$ \\
\hline & 20 & 55 & 24 & 1 \\
\hline \multirow{2}{*}{ Job } & Student & $\begin{array}{c}\text { Government } \\
\text { employees }\end{array}$ & $\begin{array}{c}\text { Non-government } \\
\text { employees }\end{array}$ & Entrepreneur \\
\hline & 58 & 3 & 26 & 13 \\
\hline \multirow[t]{2}{*}{ Origin region } & Jakarta & $\begin{array}{c}\text { Bogor/Depok/ } \\
\text { Tangerang/Bekasi }\end{array}$ & $\begin{array}{c}\text { Outside } \\
\text { Bogor/Depok/ } \\
\text { Tangerang/Bekasi }\end{array}$ & $\begin{array}{l}\text { Outside } \\
\text { Indonesia }\end{array}$ \\
\hline & 48 & 26 & 23 & 3 \\
\hline \multirow[t]{2}{*}{ Residence region } & Jakarta & $\begin{array}{c}\text { Bogor/Depok/ } \\
\text { Tangerang/Bekasi }\end{array}$ & $\begin{array}{c}\text { Outside } \\
\text { Bogor/Depok/ } \\
\text { Tangerang/Bekasi }\end{array}$ & $\begin{array}{l}\text { Outside } \\
\text { Indonesia }\end{array}$ \\
\hline & 68 & 22 & 7 & 3 \\
\hline \multirow{2}{*}{ Frequency of visit } & First time & $2-4$ times & $5-7$ times & $>7$ times \\
\hline & 15 & 41 & 25 & 19 \\
\hline \multirow{2}{*}{ Partner of visit } & Self & Friend/s & Family & $\begin{array}{l}\text { Co-worker } \\
\text { /client }\end{array}$ \\
\hline & 10 & 42 & 46 & 2 \\
\hline \multirow{2}{*}{ Duration of visit } & $1-6$ hours & $7-12$ hours & 2 days & $3-5$ days \\
\hline & 84 & 15 & - & 1 \\
\hline
\end{tabular}

Tourism Motivation Identification

Table 2

Tourism Motivation

\begin{tabular}{|c|c|c|c|c|c|c|c|}
\hline \multirow{2}{*}{ Statement } & \multicolumn{5}{|c|}{$\begin{array}{l}\text { Answer } \\
\text { (score) }\end{array}$} & \multirow{2}{*}{$\begin{array}{l}\text { Total } \\
\text { Score }\end{array}$} & \multirow{2}{*}{$\begin{array}{l}\text { Average } \\
\text { Answer }\end{array}$} \\
\hline & $\begin{array}{l}\text { VA } \\
(5)\end{array}$ & $\begin{array}{l}\mathrm{AG} \\
(4)\end{array}$ & $\begin{array}{c}\text { DBT } \\
(3)\end{array}$ & $\begin{array}{l}\text { DA } \\
(2)\end{array}$ & $\begin{array}{c}\text { VDA } \\
(1)\end{array}$ & & \\
\hline \multirow{2}{*}{$\begin{array}{l}\text { My motivation to visit TMII is } \\
\text { relaxation/health/cosiness/sport. }\end{array}$} & 54 & 41 & 3 & 2 & 0 & \multirow{2}{*}{449} & \multirow{2}{*}{$\begin{array}{l}\text { VA } \\
\text { (very } \\
\text { agree) }\end{array}$} \\
\hline & 270 & 164 & 9 & 4 & 0 & & \\
\hline \multirow{2}{*}{$\begin{array}{l}\text { My motivation to visit TMII is to know } \\
\text { culture, customs, traditions, local arts, and } \\
\text { so on. }\end{array}$} & 45 & 47 & 5 & 3 & 0 & \multirow{2}{*}{434} & \multirow{2}{*}{$\begin{array}{l}\text { VA } \\
\text { (very } \\
\text { agree) }\end{array}$} \\
\hline & 225 & 188 & 15 & 6 & 0 & & \\
\hline \multirow{2}{*}{$\begin{array}{l}\text { My motivation to visit TMII is visiting } \\
\text { relatives/meet colleagues/pilgrimage/escape } \\
\text { from boredom. }\end{array}$} & 6 & 37 & 21 & 30 & 6 & \multirow{2}{*}{307} & \multirow{2}{*}{$\begin{array}{c}\mathrm{AG} \\
(\text { agree })\end{array}$} \\
\hline & 30 & 148 & 63 & 60 & 6 & & \\
\hline \multirow{2}{*}{$\begin{array}{l}\text { My motivation to visit TMII is to aimed at } \\
\text { lifting their social status. }\end{array}$} & 8 & 8 & 5 & 40 & 39 & \multirow{2}{*}{206} & \multirow{2}{*}{$\begin{array}{c}\text { DBT } \\
\text { (doubtful) }\end{array}$} \\
\hline & 40 & 32 & 15 & 80 & 39 & & \\
\hline
\end{tabular}


Identification of tourist motivation is based on the theory of motivation belong Fandeli (2002 : 1) Physical or physiological motivation, 2) Cultural motivation, 3) Social motivation or interpersonal motivation, and 4) Prestige motivation. Of the overall tourist motivation variable data, concluded that the more dominant of respondents answered very agree on the motivation of physical or physiological. Activities undertaken respondents based on the needs of relaxation, health, comfort, sport, leisure, and so on. The second motivation is the cultural motivation. The third motivation is the social motivation, and the lowest was the prestige motivation. From the observations of researchers, found tourists who were either relax under the trees around the Api Pancasila monument and TMII inner lanes in the north. This observation results in accordance with the conclusions obtained from the analysis of questionnaire data.

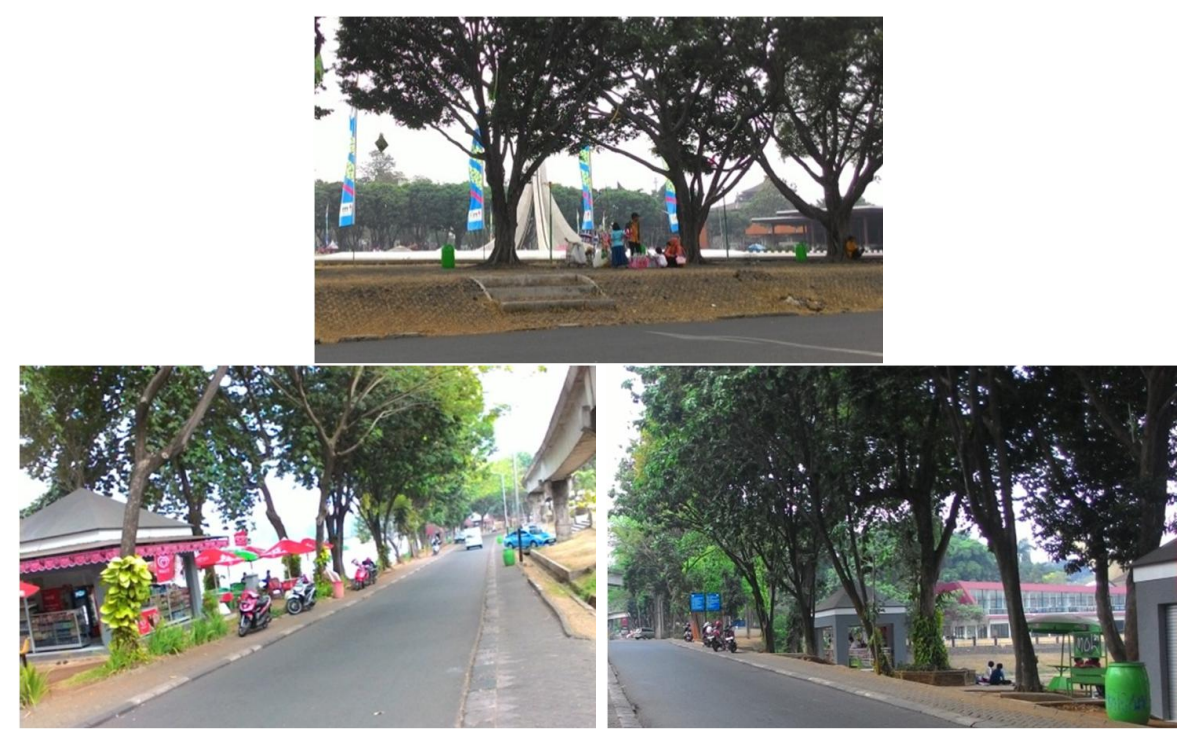

Figure 2

Condition Around Api Pancasila Monument and TMII Inner Lanes (North Side of Archipelago Lake)

\section{TMII Tourist Attraction Identification}

Table 3

TMII Tourist Attraction

\begin{tabular}{|c|c|c|c|c|c|c|c|}
\hline \multirow{2}{*}{ Statement } & \multicolumn{5}{|c|}{$\begin{array}{c}\text { Answer } \\
\text { (score) }\end{array}$} & \multirow{2}{*}{$\begin{array}{l}\text { Total } \\
\text { Score }\end{array}$} & \multirow{2}{*}{$\begin{array}{l}\text { Average } \\
\text { Answer }\end{array}$} \\
\hline & $\begin{array}{l}\text { VA } \\
\text { (5) }\end{array}$ & $\begin{array}{c}\text { AG } \\
\text { (4) }\end{array}$ & $\begin{array}{c}\text { DBT } \\
\text { (3) }\end{array}$ & $\begin{array}{l}\text { DA } \\
\text { (2) }\end{array}$ & $\begin{array}{c}\text { VDA } \\
\text { (1) }\end{array}$ & & \\
\hline \multirow{2}{*}{$\begin{array}{l}\text { Architecture of province pavilions and } \\
\text { museums decoration attractive and } \\
\text { ilustrates Indonesian cultural diversity. }\end{array}$} & 58 & 39 & 3 & 0 & 0 & \multirow{2}{*}{455} & \multirow{2}{*}{$\begin{array}{l}\text { VA } \\
\text { (very } \\
\text { agree) }\end{array}$} \\
\hline & 290 & 156 & 9 & $\mathbf{0}$ & $\mathbf{0}$ & & \\
\hline \multirow{2}{*}{$\begin{array}{l}\text { Museums in TMII which has collection of } \\
\text { cultural objects Indonesia attractive. }\end{array}$} & 55 & 39 & 4 & 2 & 0 & \multirow{2}{*}{447} & \multirow{2}{*}{$\begin{array}{l}\text { VA } \\
\text { (very } \\
\text { agree) }\end{array}$} \\
\hline & 275 & 156 & 12 & 4 & 0 & & \\
\hline
\end{tabular}




\begin{tabular}{|c|c|c|c|c|c|c|c|}
\hline \multirow{2}{*}{$\begin{array}{l}\text { Performing arts (ballet, dance, folk songs) } \\
\text { and events (rituals, ceremonies, } \\
\text { exhibitions, cultural festivals) are } \\
\text { attractive. }\end{array}$} & 47 & 46 & 5 & 2 & 0 & \multirow{2}{*}{438} & \multirow{2}{*}{$\begin{array}{l}\text { VA } \\
\text { (very } \\
\text { agree) }\end{array}$} \\
\hline & 235 & 184 & 15 & 4 & 0 & & \\
\hline \multirow{2}{*}{$\begin{array}{l}\text { Transportation in TMII area (shuttle bus, } \\
\text { Aeromovel, bike rental, Kereta } \\
\text { Gantung/cable car) are in good condition } \\
\text { and adequate. }\end{array}$} & 7 & 62 & 24 & 6 & 1 & \multirow{2}{*}{368} & \multirow{2}{*}{$\begin{array}{c}\mathrm{AG} \\
\text { (agree) }\end{array}$} \\
\hline & 35 & 248 & 72 & 12 & 1 & & \\
\hline \multirow{2}{*}{$\begin{array}{l}\text { Traditional foods \& beverages that serve } \\
\text { at food stalls in pavilion province are } \\
\text { delicious and can represents the origin } \\
\text { region. }\end{array}$} & 11 & 42 & 41 & 6 & 0 & \multirow{2}{*}{358} & \multirow{2}{*}{$\begin{array}{c}\mathrm{AG} \\
\text { (agree) }\end{array}$} \\
\hline & 55 & 168 & 123 & 12 & 0 & & \\
\hline \multirow{2}{*}{$\begin{array}{l}\text { Condition of lodging/hotel in TMII area } \\
\text { are good, comfortable, dan adequate. } \\
\text { Restaurant/food stalls (outside the } \\
\text { province pavilion) comfortable and clean. }\end{array}$} & 7 & 31 & 59 & 2 & 1 & \multirow{2}{*}{341} & \multirow{2}{*}{$\begin{array}{c}\mathrm{AG} \\
\text { (agree) }\end{array}$} \\
\hline & 35 & 124 & 177 & 4 & 1 & & \\
\hline
\end{tabular}

Table 3 shows the data of respondents interest on the tourist attraction owned by TMII: architecture, museums, performing arts and events, transportation, dining and accommodation. Statements regarding the architecture and decoration museum pavilion was answered VA by 58 respondents. Obtained total score of 447, so it can be concluded that the majority of respondents strongly agreed with the statement architecture of province pavilion and museums decoration are interesting and ilustrates Indonesian cultural diversity. Respondents who answered doubtful argued that not all museums in TMII illustrate the diversity of Indonesian culture, such as PPIPTEK and the Museum of Electricity and New Energy.

Ms. Ertis Yulia Manikam (TMII Cultural Affairs Manager) agreed that the architecture of the existing buildings in TMII describe the condition of Indonesia as a whole, both cultural diversity and local knowledge, development of technology and the diversity of religion / belief. She argues the architecture of province pavilion needs to be studied in order to be communicated to visitors as new knowledge about the culture of Indonesia. Museums decoration according to the needs of each museum, and now has begun to be reorganized so that visitors can feel more comfort. Also provided media information that facilitate the visitors to got the knowledge without having to depend on the guide.

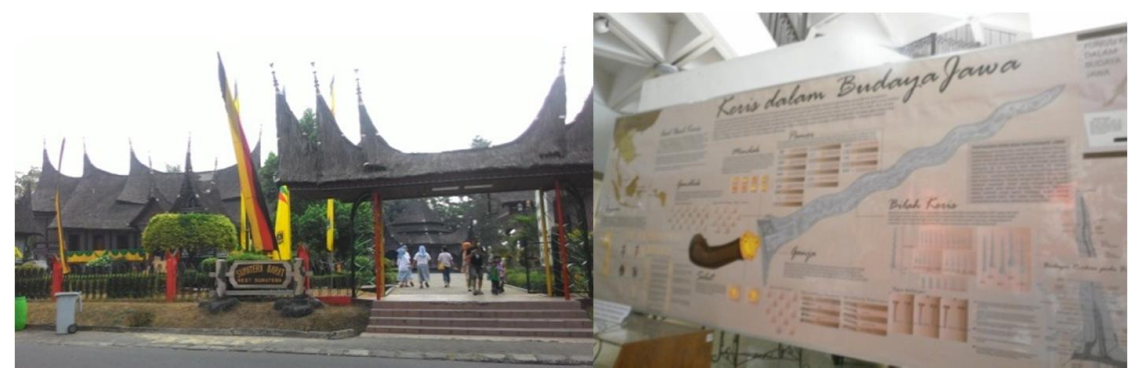

Figure 3

Sumatera Barat Pavilion and Information Media in Museum of Heirloom 
A total of 55 respondents answered VA on the statement 'museums in TMII which has collection of cultural objects Indonesia attractive'. So it was concluded the majority of respondents strongly agreed.

In the Museum of Indonesia, the collection displayed shows the cultural diversity and other matters concerning the development of public life in Indonesia. On the first floor, the collection is displayed among other traditional clothes, both everyday wear and wedding attire. On the second floor, shown traditional ceremonies diorama and matters related to people's lives in Indonesia such as the traditional house (miniature) and traditional transportation. Related collections of textiles, metal craft, to the collection of ever prevailing currency in Indonesia is on the third floor. Information that researchers get for observation is the average visitor will be directed to this museum by a guide TMII (when using the guide services), especially for the first-time visitors. The reason that researchers get from some of the guide is due to the limited time of the visit, so to get a fairly complete information about Indonesia, the guide will direct visitors to the Museum of Indonesia.

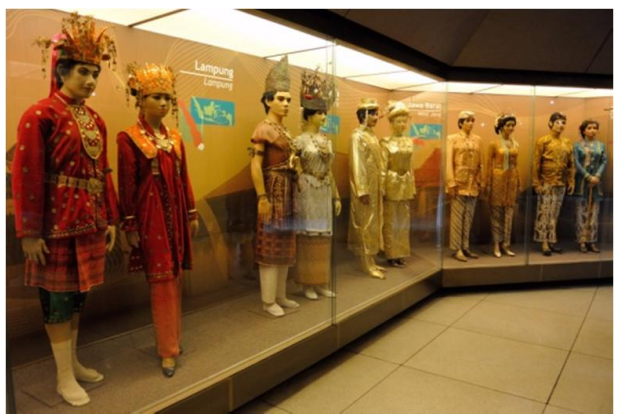

Figure 4

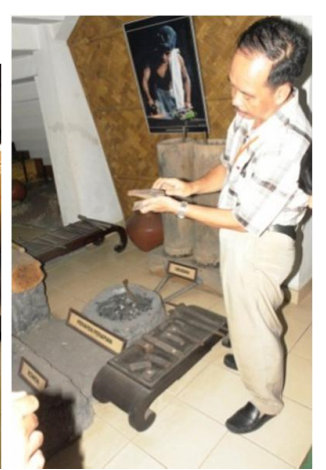

\section{Museum of Indonesia and dan Heirloom Museum Collections}

Collections at the Heirloom Museum are traditional weapons from all provinces in Indonesia. In this museum, there is a set collection of materials and tools used in the keris manufacturing process. In addition, the guide who met the researchers showed the dagger that can stand on its sharp end. It is some of the evidence by the researchers in the field related to the claim that museums in TMII which has a collection of Indonesian cultural objects are interesting. However, respondents who answered doubtful and disagree argue it should be added interesting media information in museums, especially those that have collections of cultural objects.

In the third statement of the performing arts and events in TMII, it can be concluded that majority of respondents strongly agreed with the statement performing arts (ballet, dance, song and music area) and event (rituals, ceremonies, exhibitions, cultural festivals) are attractive. Respondents who answered doubtful and disagree argues that actually cultural that performed in TMII interesting. But in its implementation, TMII parties seem less preparation and coordination. This is seen by respondents as important things in organizing a show. 
Shown in Figure 5 two performances: Parade Tari Nusantara (dance parade) and "Cupu Manik Astagina" ballet. The show was organized by the TMII management in cooperation with the manager of the provinces pavilion. At the time the researchers took the photo of Parade Tari Nusantara, enthusiasm of the audience looks of cheers and applause. These events also attract visitors from other countries. But TMII management not provided information in English like form of sheets, books, neither orally about the dances performed. The information is only on magazine published by TMII in Bahasa.

From an interview with Ms. Ertis, she said that art shows in TMII was prioritized based on Indonesian culture. She noted that there are more than 1000 cultural-based activities held in TMII annually. There are 7 national level activities that have been carried out consistently every year, Parade Tari Nusantara, Parade Lagu Daerah (regional song parade), Karnaval Keprajuritan (soldiering carnival), Parade Busana Daerah (regional fashion parade), Parade Teater Tradisi (traditional theatre parade), Parade Musik Tradisi (traditional music parade), and Pawai Budaya (cultural parade). In addition, there are also a popular band performances, contemporary performances, and so on. She also said that the competition event like Parade Tari Nusantara held not to compare the grandeur tradition with other traditions, but rather the assessment how to present the traditions of each area make it look more attractive without releasing the core values of the tradition.

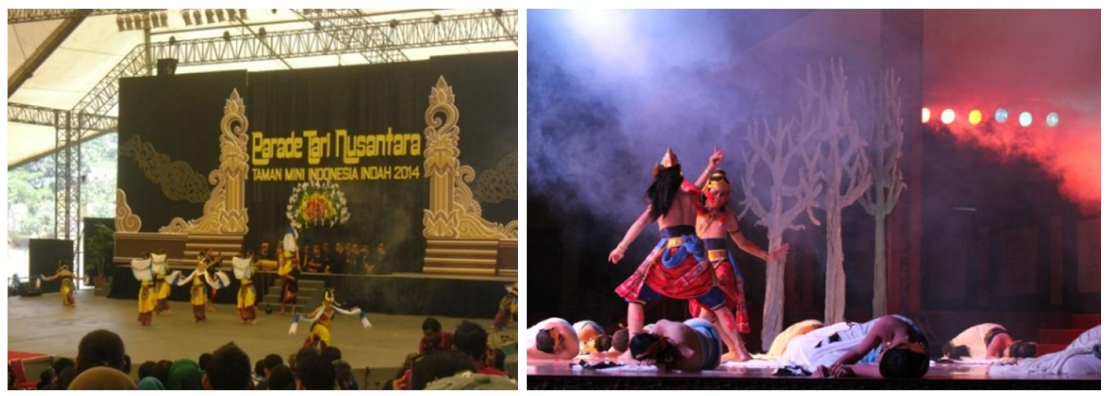

Figure 5

Performance Arts in TMII

The fourth statement is transportation in TMII is in good condition and adequate. The amount of the total score is 368 , so the conclusions is average respondents agreed with the statement that transportation in the area of TMII in good condition and adequate.

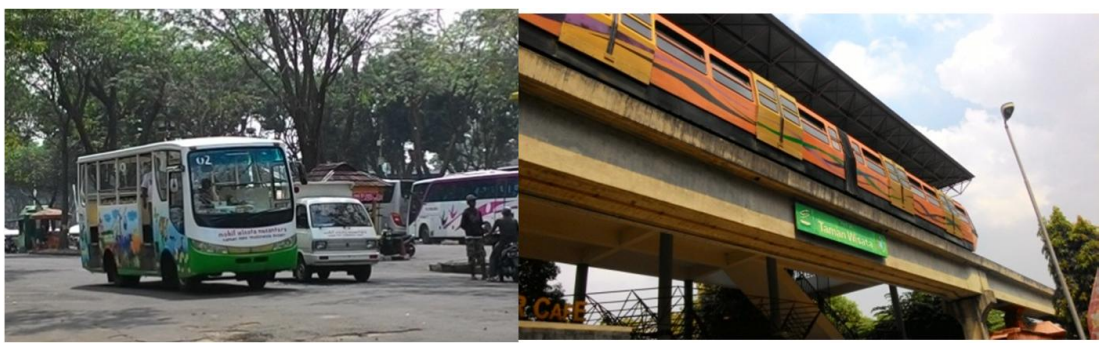

Figure 6

Transportation in TMII 
The fifth statement on regional representation through the foods and beverages at the food stalls/ pavilion cafeteria. It can be concluded that the majority of respondents agree with the statement culinary regional specialties served at the food stalls/pavilion cafeteria tasty and can represent the origin region. Meanwhile, respondents who answered disagree argue that not all pavilion have a cafeteria that serve regional cuisine. In addition, TMII management also organizes Indonesian culinary festival during certain weeks as the anniversary weekend this area. In this event, the TMII management cooperate with ambassadors from the province pavilion to provide a unique culinary of their regions. Some pavilion also planning special culinary festival, for example in West Sumatra and Aceh pavilion. In this festival, pavilion management will coordinate with TMII management, so the event does not coincide with the event held by TMII management.

The last statement is about the condition of accommodation (lodging and restaurant), and more than half of respondents agreed with the statement lodging conditions in the area of TMII is good, comfortable, and adequate, whilst restaurant/diner (outside the pavilion) is comfortable and clean. The majority of respondents who answered doubtful had never stayed at the lodge in TMII, but saw the building from the outside. Respondents who answered disagree and very disagree found there was ex-food trash in the food stalls area. They argue that lodgings in TMII needs improvement.

The final conclusion regarding TMII tourist attraction that most interesting is architecture and decoration of existing buildings in this area. The second is the museum that has a collection in the form of cultural objects, and the third is a performing arts event held in TMII. Attractiveness of adequate transportation is the fourth, culinary ranks fifth, and last is accommodation (lodging/hotel and restaurants).

\section{Cultural Tourism Activity of Interest Identification}

Table 4

Cultural Tourism Activity

\begin{tabular}{|c|c|c|c|c|c|c|c|}
\hline \multirow{2}{*}{ Statement } & \multicolumn{5}{|c|}{$\begin{array}{c}\text { Answer } \\
\text { (score) }\end{array}$} & \multirow{2}{*}{$\begin{array}{l}\text { Total } \\
\text { Score }\end{array}$} & \multirow{2}{*}{$\begin{array}{c}\text { Average } \\
\text { Answer }\end{array}$} \\
\hline & $\begin{array}{l}\text { VA } \\
\text { (5) }\end{array}$ & $\begin{array}{c}\mathbf{A G} \\
(4)\end{array}$ & $\begin{array}{c}\text { DBT } \\
\text { (3) }\end{array}$ & $\begin{array}{l}\text { VA } \\
(5)\end{array}$ & $\begin{array}{l}\text { AG } \\
(4)\end{array}$ & & \\
\hline \multirow{2}{*}{$\begin{array}{l}\text { I want to join sightseeing cultural tourism } \\
\text { activity, with activity seeing around and } \\
\text { watching cultural attraction } \\
\text { displayed/shown. }\end{array}$} & 34 & 57 & 6 & 3 & 0 & \multirow{2}{*}{422} & \multirow{2}{*}{$\begin{array}{c}\text { VA } \\
\text { (very } \\
\text { agree) }\end{array}$} \\
\hline & 170 & 228 & 18 & 6 & $\mathbf{0}$ & & \\
\hline \multirow{2}{*}{$\begin{array}{l}\text { I want to join purposeful cultural tourism } \\
\text { activity, cultural tourism activity, with } \\
\text { activity that involve tourists in cultural } \\
\text { attraction shown (i.e. ballet, making batik, } \\
\text { music performance, etc). }\end{array}$} & 33 & 53 & 13 & 1 & 0 & \multirow{2}{*}{418} & \multirow{2}{*}{$\begin{array}{l}\text { VA } \\
\text { (very } \\
\text { agree) }\end{array}$} \\
\hline & 165 & 212 & 39 & 2 & $\mathbf{0}$ & & \\
\hline \multirow{2}{*}{$\begin{array}{l}\text { I want to join incidental cultural tourism } \\
\text { activity, cultural tourism activity, with } \\
\text { main activity like race/games, modern } \\
\text { music performance, or seminar/workshop. }\end{array}$} & 26 & 56 & 12 & 5 & 1 & \multirow{2}{*}{401} & \multirow{2}{*}{$\begin{array}{l}\text { VA } \\
\text { (very } \\
\text { agree) }\end{array}$} \\
\hline & 130 & 224 & 36 & 10 & 1 & & \\
\hline
\end{tabular}


Tourist activities that demand by tourists are categorized by the type of cultural tourists (Mckercher \& Du Cros), namely the incidental cultural tourist, the casual cultural tourist, the serendipitous cultural tourist, the sightseeing cultural tourist, and the purposeful cultural tourist. Of the five types of cultural tourists, which is considered the most appropriate to the type of tourists in TMII is the incidental cultural tourist, the sightseeing cultural tourist, and the purposeful cultural tourist.

Statements regarding the activity of sightseeing cultural tourism is concluded that the majority of respondents very agree with the statement that they are interested in the activities of sightseeing cultural tourism.

Second statements regarding of purposeful cultural tourism activity. A total of 33 respondents answered VA, 53 people answered AG, 13 people answered DBT, one person answered DA, and no one answered VDA. A respondent who works as a driver of one local travel agent argues the type of purposeful cultural tourism activity is most likely not in accordance with the programs offered by the travel agent where he worked. This is because the length of tourist activity time has been determined, while the type of purposeful cultural tourist activity likely take at least one day. In the interview, Ms. Ertis argues that purposeful cultural attractions need time to prepare the necessary things. Ms. Ertis also said there are human resources who able to become teachers for tourists who want to know in depth about a culture such as batik (in Central Java pavilion), dance, or music. Purposeful cultural tourism activity according to Ms. Ertis also existed in TMII. Activities undertaken usually depends on the potential visitors requests.

In the statement of incidental cultural tourism activity, and it concluded that the majority of respondents answered strongly agreed with the statement that the respondent interested to participating in incidental cultural activities. Based on interviews that researchers do to Ms. Ertis, incidental cultural tourism activity has often exist in TMII. An example is the tourists who visited Jakarta for a seminar or training purposes. To fill the empty time after the seminar is finished, organizers of the event contact TMII management to require the provision of facilities and organizers for the participants to visit this area. According to Ms. Ertis, TMII management undertakes to prepare the guest's needs in one day, during a committee or a leader can communicate. Guests like this not only from abroad, but also the national and local tourists as from schools.

The conclusion from the data regarding the activity of cultural tourism interest is most respondents are interested in participating to the activities of sightseeing cultural tourism. Purposeful cultural tourism activity chosen as a second choice, and incidental cultural tourism activity is the third option. In an interview, Ms. Ertis argued that the three concepts of cultural tourism products are suitable to be applied in TMII. Ms. Ertis also said that tourist activity associated with the formation, development, and utilization of culture can be done in TMII. These activities must be carried out in a balanced and still adapted to the needs and existing infrastructure. "Activity itself in art, TMII have studios for dancing, music, singing, there karawitan, pedalangan wayang, playing angklung also taught, painting in Desa Seni. Facilitated the education community, who want to learn it there all in TMII and was also programmed routine, they can choose. But 
perhaps people from outside are also much less know that here they can learn it", she said. From what was presented by Ms. Ertis in the interview, it was found that the facilities and arts learning programs already exist, but lack of promotion to tourists who come, so many of them do not know it. In fact, if the promotion of the arts learning program can be enhanced, tourists can get a deeper cultural tourism experience. The program can also be arranged so it can accordance with tourists travel motivations and their activities of interest.

\section{Cultural Tourism Products Proposed}

In this study used several theories to arrange activities such as what is in accordance with the results of research in the field. The theories used are the criteria of socio-cultural tourism by Gearing et al. (1976) and the case forming the total experience by COMCEC (2013). Socio-cultural tourist criteria are:

1) Customs; such as clothing, food, ceremonies or rituals.

2) Art of the building; architecture and traditional decor of pavilion and museum.

3) Stage, performances, and festivals; such as ballet, dances, songs and folk music, exhibitions, or a cultural festival.

Theory, forming a total experience that is experiential, emotional, and physical. However, the theory used in this study is the experience and physical, because to shape the form of emotional experience (between tourists and local communities) it takes a long time and intense interaction. This is not in accordance with the findings that respondents were more interested in sightseeing cultural tourism activities. Below the explanation of this theory.

1) Experience

The experience gained from the activities undertaken, festivals, entertainment, food and beverage.

2) Physical

The experience gained from tangible objects such as infrastructure, accommodation, restaurants, and souvenir shops.

Planning of cultural tourism products made by researcher based on respondents tourism motivation, tourist attraction TMII and cultural tourism activities with the highest scores: physical or physiological motivation, a tourist attraction in the form of architecture and decoration, and activities of sightseeing cultural tourism. 
Table 5

Cultural Tourism Product Proposed

\begin{tabular}{|c|c|c|c|c|c|c|}
\hline \multirow[b]{2}{*}{ Activities } & \multirow[b]{2}{*}{ Location } & \multicolumn{3}{|c|}{ Criteria of Socio-Cultural Tourism } & \multicolumn{2}{|c|}{$\begin{array}{c}\text { Case Forming the Total } \\
\text { Experience }\end{array}$} \\
\hline & & Customs & $\begin{array}{l}\text { Art of the } \\
\text { building }\end{array}$ & $\begin{array}{c}\text { Stage, } \\
\text { performanc } \\
\text { es, and } \\
\text { festivals } \\
\end{array}$ & Experience & Physical \\
\hline $\begin{array}{l}\text { Aerobic using mixes } \\
\text { contemporary and } \\
\text { traditional movement } \\
\text { and music }\end{array}$ & $\begin{array}{c}\text { Candi } \\
\text { Bentar } \\
\text { Area }\end{array}$ & & $\sqrt{ }$ & $\sqrt{ }$ & $\sqrt{ }$ & $\sqrt{ }$ \\
\hline $\begin{array}{l}\text { Taking photo using } \\
\text { traditional clothing }\end{array}$ & $\begin{array}{l}\text { Province } \\
\text { Pavilions }\end{array}$ & $\sqrt{ }$ & $\sqrt{ }$ & & $\sqrt{ }$ & $\sqrt{ }$ \\
\hline $\begin{array}{l}\text { Going around TMII } \\
\text { using traditional } \\
\text { transportation (i.e. } \\
\text { delman) }\end{array}$ & $\begin{array}{c}\text { TMII } \\
\text { inner lane }\end{array}$ & & $\sqrt{ }$ & & $\sqrt{ }$ & $\sqrt{ }$ \\
\hline $\begin{array}{l}\text { Playing traditional } \\
\text { musical instruments }\end{array}$ & $\begin{array}{l}\text { Province } \\
\text { Pavilions }\end{array}$ & & $\sqrt{ }$ & $\sqrt{ }$ & $\sqrt{ }$ & $\sqrt{ }$ \\
\hline $\begin{array}{l}\text { SPA with Indonesian } \\
\text { traditional herbs }\end{array}$ & $\begin{array}{c}\text { Desa } \\
\text { Wisata } \\
\text { Hotel \& } \\
\text { Resort (no } \\
\text { facilities } \\
\text { yet) }\end{array}$ & $\sqrt{ }$ & & & $\sqrt{ }$ & $\sqrt{ }$ \\
\hline
\end{tabular}

These activities can be offered to tourists per activity or used as a package that contains some activities. Performing arts that have been scheduled can also be combined with these activities. Accommodation such as Desa Wisata Hotel \& Resort and Pecel Madiun restaurant can be used to increase the physical experience of tourists through the facilities, products, and services. Existing transportation can also added to increase tourists experience. Moreover, the coordination of related fields are also needed. Examples of cultural tourism products that can be applied from the start of the visit as follows.

○ Going around TMII using traditional transportation. Tourists picked up by delman from the parking area or TMII entrance to get around through the lane, back to the north or south parking area.

- Take pictures using traditional clothing. Tourists escorted by a TMII tour guide by shuttle bus/car to province pavilion chosen to take pictures with traditional clothing that has been prepared by pavilion management and see architecture of traditional houses accompanied by the guide. On the 
sidelines of this activity, TMII tour guide can offer to tourists if they want to visit the museum or watch the performances that have been scheduled.

- After taking pictures, tour guide directing tourists to have lunch with a menu of traditional cuisine. Lunch location can be adjusted with the next activity, which playing traditional musical instruments together in the pavilion. Pavilion chosen as the location for the lunch can be the same as the location of playing traditional musical instruments together, or may have been the different pavilion which are located adjacent areas (eg lunch location in East Java Pavilion, the location of playing music together in Central Java Pavilion, etc.). Besides, we can also take advantage of a restaurant or food stalls provide traditional culinary, while also considering a near one from the location of playing music together.

\section{References}

Anonymous. 2015. Informasi Mengenai Pengertian dan Definisi Wisata Budaya, Online: $\quad$ http://www.wisatamu.com/pengertian-wisata-budaya.html, accessed on April, 23th 2015 at $09.30 \mathrm{pm}$.

Guha, Sutithee. 2009. Motivational Push Factors for Visiting Reenacment Sites. Tesis. Michigan: San Jose State University.

Hermantoro, Henky. 2015. Kepariwisataan, Destinasi Pariwisata, dan Produk Pariwisata. Depok: Aditri.

Mckercher, Bob and Hilary Du Cros. 2012. Cultural Tourism: The Partnership Between Tourism and Cultural Heritage Management. Oxon: Routledge.

Mohammad, Bashar A.M.A. and A.P. Mat Som. 2010. "An Analysis of Push and Pull Travel Motivations of Foreign Tourists to Jordan". International Journal of Business and Management, Volume 5 Nomor 12, Hlm.41.

Nirwandar, Sapta. 2014. Building WOW Indonesia Tourism and Creative Industry. Jakarta: PT Gramedia Pustaka Utama.

Patria, Teguh A. 2014. Paris Jual Wisata Budaya, Online: http://hotelmanagement.binus.ac.id/2014/01/02/paris-jual-wisata-budaya/, diakses pada 24 April 2015 pukul 10.00 WIB.

Pitana, I G. dan Diarta, I K.Surya. 2009. Pengantar Ilmu Pariwisata. Yogyakarta: CV Andi Offset.

Sawitri, Niken I. dkk. 2013. "Hubungan Karakteristik Wisatawan dan Motivasinya di Taman Hutan Raya Ir. H. Djuanda". Antologi Manajemen Resort \& Leisure, Volume 1 Nomor 2.

Sheldon, J.Pauline. 1997. Tourism Information Technology. Wallingford: CABI.

Singh, Shalini. 2009. Domestic Tourism in Asia: Diversity and Divergence. London: Earthscan.

Sugiyono. 2009. Metode Penelitian Kuantitatif, Kualitatif dan $R \& D$. Bandung: Alfabeta.

World Economic Forum. 2013. The Travel \& Tourism Competitiveness Report 2013, Online: http://www3.weforum.org/docs/WEF_TT_Competitiveness_Report_2013. pdf, diakses pada 20 Maret 2015 pukul 19.48 WIB. 
World Tourism Organization. 2014. UNWTO Annual Report 2013, Online: http://www2.unwto.org/publication/unwto-annual-report-2013, diakses pada 20 Maret 2015 pukul 15.36 WIB. 